\title{
Compressive Strength of a Glass lonomer Cement Under the Influence of Varnish Protection and Dietary Fluids
}

\section{Resistencia a la compresión de un cemento de ionómero de vidrio bajo la influencia de la protección del barniz y diversos productos alimenticios}

\author{
Bohner L.0.L. DDS, MSc, PhD¹; Prates L.H.M. DDS, MSc, PhD² \\ 1. Doctor of Dental Surgery, former student, undergraduate from Dentistry Course at the Federal \\ University of Santa Catarina (UFSC) Florianópolis, Santa Catarina, Brazil. \\ 2. Professor of Dental Materials, Dentistry Course, at the Federal University of Santa Catarina (UFSC), \\ Florianópolis, Santa Catarina, Brazil.
}

Correspondence to: Prates L.H.M. - luiz.prates@ufsc.br

Received: 24-IV-2018

Accepted: $31-\mathrm{V}-2018$

Published Online First: 12-VI-2018

DOI: https://doi.org/10.15517/ijds.v0i0.33607

\section{ABSTRACT}

The objective of this study was to evaluate the compressive strength of a glass ionomer cement (GIC) under the influence of varnish protection and dietary fluids. Eighty cylindrical test specimens were made from GIC and distributed into four groups (G1, G2, G3, G4) according to the dietary fluid. Each group was further divided into subgroups $A$ and $B$ according to the presence or absence of varnish protection. The eight subgroup samples were stored in distilled water for 30 days and received the following treatments for 14 days: G2A: varnish protection and immersion in soft drink, G2B: no varnish protection and immersion in soft drink, G3A: varnish protection and immersion in orange juice, G3B: no varnish protection and immersion in orange juice, G4A: varnish protection and immersion in yogurt, G4B: no varnish protection and immersion in yogurt. The immersion procedure was performed three times a day, for 15 minutes at a time, for a total of 14 days. The samples from subgroups G1A (with varnish) and G1B (without varnish) were used as controls and stored in distilled water only for 30 days. The samples were submitted to a compressive strength test after the immersion period. The results were analyzed using the ANOVA 2, Tukey test (5\%) and Student's t-test (5\%). There were no significant differences between the subgroups, except for the subgroup with varnish protection and immersion in orange juice, which showed reduced GIC compressive strength.

\section{KEYWORDS}

Glass ionomer cements; Tooth erosion; Dental restoration wear; Compressive strength. 


\section{RESUMEN}

El objetivo de este estudio fue evaluar la resistencia a la compresión de un cemento de ionómero de vidrio (GIC) bajo la influencia de la protección del barniz y alimentos. Ochenta muestras cilíndricas de GIC fueron realizadas y se distribuyeron en cuatro grupos $(\mathrm{G} 1, \mathrm{G} 2, \mathrm{G} 3, \mathrm{G} 4)$ de acuerdo con el alimento. Cada grupo se sub-dividió además en $\mathrm{A}$ y $\mathrm{B}$, de acuerdo con la presencia 0 ausencia de protección de barniz. Las ocho muestras de cada subgrupo se almacenaron en agua destilada durante 30 días y recibieron Ios siguientes tratamientos durante 14 días: G2A: protección del barniz e inmersión en gaseosas, G2B: sin barniz e inmersión en gaseosas, G3A: protección del barniz e inmersión en jugo de naranja, G3B: sin protección de barniz e inmersión en jugo de naranja, G4A: protección de barniz e inmersión en yogurt, G4B: sin protección de barniz e inmersión en yogur. El procedimiento de inmersión se realizó tres veces al día, durante 15 minutos por 14 días. Las muestras del Subgrupo G1A (con barniz) y G1B (sin barniz) se usaron como controles y se almacenaron en agua destilada. Las muestras se sometieron a una prueba de resistencia a la compresión después del período de inmersión. Los resultados se analizaron usando ANOVA 2, prueba de Tukey (5\%) y T de Student (5\%). No hubo diferencias significativas entre los subgrupos, a excepción del subgrupo con protección de barniz e inmersión en jugo de naranja, que mostró una resistencia a la compresión GIC reducida.

\section{PALABRAS CLAVE}

Ionomero de vidrio; Erosion dental, Fuerza de compresión.

\section{INTRODUCTION}

Dental caries is the most common oral disease and has greater incidence in socioeconomically vulnerable populations whose access to health promotion and curative treatments is limited (1). Atraumatic restorative treatment (ART) is essential for treating dental caries because of its low cost and inexpensive equipment (2). In ART, the decalcified tooth tissue is removed, and the cavity is filled with an adhesive filling material such as glass ionomer cement (3).

When selecting the ideal restorative material, the clinical situation and the material's properties such as biocompatibility, adhesion to the tooth structure, mechanical resistance, ease of handling and cost (4) must be considered. Glass ionomer cement has become widely used for restorations, as it releases fluorides, has satisfactory biocompatibility, adheres to the tooth structure and has a low coefficient of thermal linear expansion (5). Some authors have demonstrated that fluoride release increases in the presence of acidic products (6). On the other hand, it has been reported that exposure to an acidic medium can lead to material erosion (7).

High-viscosity glass ionomer cements have been recently developed. They show greater wear resistance and fluoride release in comparison with conventional glass ionomer cements and with some resin-modified glass ionomers (8). In Brazil, cements specifically developed for the ART technique have high cost and are inaccessible in certain regions of the country. Thus, national restorative glass ionomers are commonly used in Brazil $(9,10)$. A large number of studies to assess glass ionomer cements did not consider their physical properties under different variables, particularly under conditions simulating the oral cavity (2).

In the mouth, glass ionomer cements undergo changes due to acid-base chemical reactions, which lead to an initially increased hardness and subsequent material disintegration. Since 
water is part of the matrix formation process, early exposure to moisture or excess water can cause changes to the glass ionomer, and, thus, maintaining the water balance is necessary (2). According to Towler et al (11), storage in water in the first 15 minutes after a setting reaction forms a soft superficial layer, probably causing a chemical reaction inhibition that could restrict the glass ionomer's caries prevention potential.

Glass ionomer cements can absorb water and undergo dehydration (11). The use of surface protection is therefore recommended to minimize these effects and is essential for maintaining the hardness of the glass ionomer. According to Shintome et al (2), the efficacy of the protection is related to its resistance to disintegration, low permeability and hydrophobic nature.

The patients' diet is rich in fluids, and acid intake increases as new products become available in the market. Studies have shown that an acidrich, low-pH diet can lead to dental erosion and predisposition to caries. It can also compromise the physical characteristics of restorative materials (1214). The erosion of a material can be defined as its degradation in its environment. This phenomenon is characterized by dissolution of the material's matrix that leads to loss of superficial structure (7). According to Yip \& To (13), acid leads to increased surface roughness and plaque retention and susceptibility to gum inflammation.

It is relevant to investigate a restorative cement that includes the following variables: the effect that dietary fluids have on the mechanical properties of glass ionomer cements, which is still not clear, especially in the first hour after setting; and the effect that a fluoride varnish can have when used as surface protection. Answering these questions will contribute to improving the ART technique. The objective of this study was to evaluate the mechanical strength of a conventional restorative glass ionomer cement (MAXXION R-GM) in compression tests, under the influence of a fluoride varnish (Duofluorid XII-FGM) protection and immersion in dietary fluids (distilled water, Coca-Cola soft drink, Fruthos orange juice and DoVale yogurt). The two null hypotheses are the following: dietary fluid does not influence the glass ionomer cement's compressive strength and surface protection, or lack of protection does not influence the glass ionomer cement's compressive strength.

\section{MATERIALS AND METHODS}

This study used the MAXXION R (FGM) conventional glass ionomer cement, recommended as a restorative material.

To check the applicability of the method, a pilot test similar to the method described in ADA (American Dental Association) Specification no. 96/1994 (15) was performed using 12 specimens, prepared and submitted to compression tests. A stainless steel bipartite metallic matrix with five cylindrical holes measuring $4 \mathrm{~mm}$ in diameter $x 6 \mathrm{~mm}$ in height was used to make the test specimens. The cement was mixed according to the manufacturer's recommendations, using a plastic spatula and a glass plate. The matrix was placed on the glass plate, interposed with a polyester strip, and filled with cement. After the cement insertion, a second polyester strip and a second glass plate were placed atop the matrix. Light pressure was applied to flow the excess cement. After mixing, the cement was inserted into the set in less than two minutes to reduce contact with air. A clip was placed to prevent the plate from moving. The set was kept in $100 \%$ relative humidity at $37^{\circ} \mathrm{C}$ for one hour. The samples were removed, and those that presented defects or flaws were discarded. Subgroup A samples were protected with fluoride varnish (Duofluorid XII - FGM), while Subgroup B samples were not protected. The samples were placed in duly identified vials and stored in distilled 
water for 24 hours prior to being immersed in dietary fluids. All the test specimens were stored in distilled water for 30 days. They were immersed in dietary fluids for 14 days, as shown in Table 1. The distilled water was removed, and the vial was filled with the corresponding dietary fluid three times a day. The test specimen was immersed in the fluid for 15 minutes each time and then removed. The vial was refilled with distilled water afterwards. The immersion process consisted of each group undergoing 42 cycles of 15 minutes each, totaling 630 minutes (10 hours and 30 minutes) of immersion. The control groups, in which distilled water was the storage fluid, did not undergo this process.

The investigational phase included the manufacture of 80 test specimens in a manner similar to the pilot test. They were randomly assigned into four groups, according to the storage fluid. Group 1 (G1) was the control group, stored in distilled water for 30 days. Samples from the other groups were also stored in distilled water and immersed in the following fluids: Group 2 (G2): immersion in soft drink (Coca-Cola); Group 3 (G3): immersion in orange juice (Fruthos); and Group 4 (G4): immersion in yogurt (DoVale). The brands were chosen according to price and availability. Each group was further subdivided into two subgroups ( $A$ and $B$ ), according to the presence or absence of a surface protection (Table 1). The test specimens underwent the compressive strength test after the storage and immersion cycle as follows: 10 samples per subgroup and 20 per group.
Table 1. Test specimen distribution into groups/ subgroups, according to the immersion fluid and presence or absence of surface protection varnish.

\begin{tabular}{ccc}
\hline Group/subgroup & $\begin{array}{c}\text { Immersion } \\
\text { fluid }\end{array}$ & $\begin{array}{c}\text { Protection } \\
\text { varnish } \\
\text { application }\end{array}$ \\
\hline G1A & Water & Yes \\
G1B & Water & No \\
G2A & Soft drink & Yes \\
G2B & Soft drink & No \\
G3A & Orange juice & Yes \\
G3B & Orange juice & No \\
G4A & Yogurt & Yes \\
G4B & Yogurt & No \\
\hline
\end{tabular}

\section{COMPRESSIVE STRENGTH TESTS}

The samples were placed in a mechanical test machine (Instron, 4444) for the compressive strength tests. A compression load was applied at $0.5 \mathrm{~mm} / \mathrm{min}$ speed until the test specimens were fractured. The following formula was applied to the results, in newtons ( $N)$ : $C R=4 p / \pi d^{2}$, where $\mathrm{CR}=$ compression resistance, in megapascals (MPa), $\mathrm{p}=$ maximum load applied to the sample, in newtons (N), $\pi=$ constant 3.1416 and $d=$ sample diameter, in millimeters $(\mathrm{mm})$.

The values obtained in the compressive strength tests were analyzed using the ANOVA 2, Tukey test (5\%) and Student's t-test (5\%) to check the existence of statistically significant differences. 
RESULTS

The mean values obtained in the compressive strength test for the MAXXION R glass ionomer cement, according to cement immersion in different dietary fluids for 14 days and the presence or absence of surface protection varnish, are shown in Table 2. The first null hypothesis was accepted after statistical data analysis (ANOVA 2 and Tukey (5\%)), i.e., immersion in dietary fluids did not significantly affect the glass ionomer cement compressive strength compared to immersion in distilled water $(p>0.05)$. The second null hypothesis was partially proven after the application of Student's t-test $(5 \%)$, i.e., protection varnish did influence the compressive strength values, which were reduced when the samples were immersed in orange juice $(p<0.05)$. No statistically significant effect was observed for the other fluids (distilled water, soft drink and yogurt) ( $p>0.05)$.

Table 2. Mean compressive strength values (MPa) for the test specimens, according to the dietary fluid and presence or absence of surface protection varnish $(\mathrm{N}=10)$.

\begin{tabular}{cccc}
\hline Group & Immersion fluid & $\begin{array}{c}\text { With protection varnish } \\
\text { (Subgroup A) }\end{array}$ & $\begin{array}{c}\text { Without protection varnish } \\
\text { (Subgroup B) }\end{array}$ \\
\hline G1 & Distilled water & $35.71(17.63) \mathrm{Aa}$ & $40.46(22.85) \mathrm{Aa}$ \\
G2 & Soft drink & $35.48(14.03) \mathrm{Aa}$ & $41.22(12.25) \mathrm{Aa}$ \\
G3 & Orange juice & $32.95(12.84) \mathrm{Aa}$ & $52.50(15.15) \mathrm{Ab}$ \\
G4 & Yogurt & $39.46(14.48) \mathrm{Aa}$ & $44.05(20.18) \mathrm{Aa}$ \\
\hline
\end{tabular}

*Standard deviation in brackets.

*Mean values indicated by the same uppercase letters in a column are statistically similar using the ANOVA and Tukey test ( $p>0.05$ ).

*Mean values indicated by different lowercase letters in a line are significantly different using Student's t-test $(p<0.05)$.

\section{DISCUSSION}

This study evaluated the hypothesis that dietary fluids have an effect on the compressive strength of a conventional glass ionomer cement, with or without fluoride varnish protection. Compressive strength is an important property for restorative materials, as it represents tensions that occur during chewing (16). Moreover, Lima et al (7) have reported that there is little specific information regarding the action of fluids on glass ionomer cements, which justified the need for investigation.

Acid resistance is a property that should be considered when selecting the restorative material (17). In this regard, Khoroushi \& Keshani (18) consider the high values of solubility and erosion, especially under acidic conditions, disadvantages of glass ionomer cements.
However, the results obtained in this study showed that, compared to distilled water, the different dietary fluids (soft drink, orange juice and yogurt) did not have a negative effect on the compressive strength of a conventional glass ionomer cement (Table 2). Furthermore, varnish protection significantly interfered with and reduced compressive strength only when the samples were immersed in orange juice.

Contradictory results have been mentioned in the literature. Lima et al (7) reported that acidic beverages such as Coca-Cola and sugarcane juice caused changes to the surface of a conventional glass ionomer. Corroborating this information, Braga et al (19) observed that acidic beverage ingestion followed by brushing causes degradation of the resin-modified glass ionomer. Wang et al (16) observed that the Young's modulus of glass 
ionomer cement was not significantly changed after immersion in a lactic acid solution. This is similar to the results obtained in our study.

A possible explanation for the different results obtained in the literature is related to the different methods used and the properties evaluated. Studies of surface properties show a higher probability of significant influence from storage media on the glass ionomer cement, as observed by Lima et al (7) and Braga et al (19). On the other hand, studies that evaluated the effect of certain storage media on the internal structure of glass ionomer cements showed that the differences were not significant, as observed by Wang et al (16) and in this study.

Therefore, the hypothesis that changes occur predominantly on the material surface, without significant internal changes to compressive strength when the glass ionomer cement is submitted to certain dietary fluids, especially acidic $\mathrm{pH}$ values, is reinforced. It should be highlighted that in this study, the storage period was 30 days, and immersion in the respective fluids occurred three times a day, 15 minutes each, for 14 days. It is possible that longer periods of contact with the solutions could cause significant differences. Using different methods and/or variables can yield different results, which can be evaluated in the future.

In this study, the test specimens were stored in distilled water, and the conditions of the oral cavity were not taken into consideration. According to Yip \& To (13), glass ionomer properties can change depending on the osmolarity of the medium. As observed in this study, certain dietary fluids do not significantly influence the glass ionomer compressive resistance. This should not encourage changing habits or techniques, as changes to the material surface can occur in contact with acidic beverages and brushing, as reported by Braga et al (19). In addition, changes to other properties, such as solubility, which were not evaluated in this study, can occur as reported by Felemban \& Ebrahim (20).

Another variable evaluated in this study was protection of the glass ionomer cement, i.e., the presence or absence of fluoride varnish on the material surface prior to its immersion in the different dietary fluids. Given that glass ionomer cements are vulnerable to syneresis and soaking, surface protection during the gelation process is important (20).

Shintome et al (2) observed that both surface protection and storage time in distilled water can increase the glass ionomer cement microhardness values, thus reinforcing the hypotheses. Glass ionomer cement compressive strength is regulated by water balance from the start of the reaction until the end of gelation. Final cement resistance is reached within 24 hours (2). Protection against the external environment is recommended in the first hours to allow for full gelation (21).

In this study, protection was applied one hour after test specimen manufacture in half of the samples for each group, corresponding to a specific dietary fluid, before they were immersed in distilled water. With regard to compressive strength, it was observed that the varnish-protected glass ionomer cement samples did not show statistically significant differences compared to the unprotected cements in most fluids (water, soft drink and yogurt). Nevertheless, numerically lower values were observed in the subgroups in which the test specimens were protected with varnish. The subgroup with varnish protection presented statistically lower compressive strength values when the sample was immersed in orange juice in comparison with the unprotected subgroup (Student's t-test, $p<0.05$ ).

The hypothesis used to discuss the effect of dietary fluids explains the inexistence of greater differences: a possible influence would be at 
the material surface level for the groups with no varnish protection. However, in a study by Pilo et al (22), protected glass ionomer cements presented reduced compressive strength values compared to unprotected cements. According to the authors, sealing by surface protection makes it difficult for the cement to absorb water during the gelation process and prevents the full development of cement resistance. This might have occurred in the subgroup protected with varnish and immersed in orange juice (22). A non-statistically significant numerical reduction in ionomer compressive strength was also observed in this study when the samples were protected with varnish and immersed in water, soft drink and yogurt. This might have occurred because test specimen protection was performed one hour after their manufacture, i.e., when the chemical gelation reaction was advanced.

It was also observed that the mean compressive strength values for all groups were much lower than the minimum established by the American Dental Association Specification no. 96 for restorative ionomers, namely, $130 \mathrm{MPa}$ (15). In this study, the compressive strength tests were performed 30 days after sample manufacture, not 24 hours after sample manufacture, as recommended in the Specification. Our objective was to check the possible influence dietary beverages and surface protection can have on this property. Therefore, the mean values observed in this study cannot be assigned exclusively to the ionomer investigated. An evaluation that strictly complies with the standards set in Specification no. 96 must be undertaken (15).

Lastly, new studies involving variables not evaluated in this study can be conducted to provide additional clarification with regard to the effect dietary fluids and protection agents can have on the properties of glass ionomer cements.

\section{CONCLUSION}

Considering the limitations of laboratory research and given the results obtained, the following conclusions can be drawn:

- Immersion in dietary fluids (soft drink, orange juice and yogurt) did not influence the MAXXION R conventional glass ionomer cement compressive strength in comparison with immersion in distilled water.

- Protecting the glass ionomer cement surface with fluoride varnish caused a statistically significant change and reduced compressive strength only when the samples were immersed in orange juice. No significant differences were observed when the samples were protected with varnish and immersed in the other fluids (distilled water, soft drink and yogurt). 


\section{REFERENCES}

1. Paganelli, A. P. D., Constance, H. M., Sala, F. S., Bainha, C. C., Borges, A. L. S. Jr., Bastos, J. L., Peres, M. A. Trends in dental caries rates over 45 years (1971-2016) among schoolchildren in Florianópolis, southern Brazil. Int. Dent. J. 2017; 68 (1): 47-53.

2. Shintome L. K., Nagayassu M. P., Di Nicoló R., Myaki S. I. Microhardness of glass ionomer cements indicated for the ART technique according to surface protection treatment and storage time. Braz. Oral Res. 2009; 23 (4): 439-445.

3. Frencker, J. E. Atraumatic restorative treatment and minimal intervention dentistry. Br Dent J. 2017; 223 (3): 183-189.

4. Ferreira F. M., Vale M. P. P., Jansen W. C., Paiva S. M., Pordeus I. A. Performance of Brazilian and imported glass ionomer cements used in Atraumatic Restorative Treatment (ART) regarding microleakage in primary molars. J. Appl. Oral Sci. 2006; 14 (5): 312-318.

5. Hafshejani T. M., Zamanian A., Venugopal J. R., Rezvani Z., Sefat F., Saeb M. R., Vahabi H., Zarrintaj P., Mozafari M. Antibacterial glass-ionomer cement restorative materials: a critical review on the current status of extended release formulations. J Control Release. 2017; 262: 317-328.

6. De Moor R. J. G., Martens, L. C., Verbeeck R. M. H. Effect of a neutral citrate solution on the fluoride release of conventional restorative glass ionomer cements. Dent Mater. 2005; 21 (4): 318-323.

7. Lima A. L., Valença A. M. G., LIMA S. J. G., Alexandria A. K. F., Claudino L. V., Silva N. B. Estudo in vitro da ação da água de coco e caldo de cana sobre a superfície de restaurações estéticas. Pesq Bras Odontoped Clin Integr. 2007; 7 (1): 43-50.
8. Kucukyilmaz E., Savas S., Kavrik F., Yasa B., Botsali M. S. Fluoride release/recharging ability and bond strength of glass ionomer cements to sound and caries affected dentin. Nigerian J Clin Practice. 2017; 20 (2): 226-234.

9. França T. R. T., Sedycias M., Silva R. J., Beatrice L. C. S., Silva C. H. V. Use of glass ionomer cements: a systematic review. Pesq Bras Odontoped Clin Integr. 2010; 20 (2): 301-307.

10. Fragnan L. N., Bonini G. A., Politano G. T., Camargo L. B., Imparato J. C. P., Raggio D. P. Knoop hardness of three glass ionome cements. Pesq Bras Odontoped Clin Integr. 2011; 11 (1): 73-76.

11. Towler M. R., Bushby A. J., Billington R. W., Hill R. G. A preliminary comparison of the mechanical properties of chemically cured and ultrasonically cured glass ionomer cements, using nano-indentation techniques. Biomat. 2001; 22 (11): 1401-1406.

12. Yap A. U. J., Mah M. K. S., Lye C. P. H., Loh P. L. Influence of dietary simulating solvents on the hardness of provisional restorative materials. Dent Mater. 2004; 20 (4): 370-376.

13. Yip H. K., To W. M. An FTIR study of the effects of artificial saliva on the physical characteristics of the glass ionomer cements used for art. Dent Mater. 2005; 21 (8): 695-703.

14. Leite T. M., Bohaienko L. A., Luciano M., Pilllati G. L., Pereira S. K. Influência de substâncias com $\mathrm{pH}$ ácido sobre a microdureza de resinas compostas. Stomatos. 2010; 16 (30): 21-32.

15. American Nacional Standard Institute. American Dental Association. Specification no 96. Dental water-basedcementes, 1994.

16. Wang L., Cefaly D. F. G., Santos J. L., Santos J. R., Lauris J. R. P., Mondelli R. F. L., Atta M. T. In vitro interactions between lactic acid solution and art glass-ionomer cements. J. Appl. Oral Sci. 2009; 17 (4): 274-279. 
17. Hengtrakool C., Kukiattrakoon B., KedjaruneLeggat $U$. Effect of naturally acidic agents on microhardness and surface micromorphology of restorative materials. Eur J Dent. 2011; 5 (1): 89-100.

18. Khoroushi M., Keshani F. A review of glassionomers: From conventional glass-ionomer to bioactive glass-ionomer. Dent Res J. 2013; 10 (4): 411-420.

19. Braga S. R. M., Garone N. Neto, Soler J. M. P., Sobral M. A. P. Degradação dos materiais restauradores utilizados em lesões cervicais não cariosas. Rev Gaúcha Odontol. 2010; 58 (4): 431-436.
20. Felemban N. H., Ebrahim M. Effects of adding silica particles on certain properties of resin-modified glass-ionomer cement. Eur J Dent. 2016; 10 (2): 225-229.

21. Kanik O., Turkun L. S., Dasch W. In vitro abrasion of resin-coated highly viscous glass ionomer cements: a confocal laser scanning microscopy study. Clin Oral Investig. 2017; 21 (3): 821-829.

22. Pilo R., Ben-Amar A., Barnea A., Blasbalg Y., Levartovsky $\mathrm{S}$. The effect of resin coating on the shear punch strength of restorative glass ionomer cements. Clin Oral Invest. 2017; 21 (4): 1079-1086. 